\title{
SUPPORTING HIGH-TECHNOLOGY SYSTEMS DURING PERIODS OF EXTENDED LIFE-CYCLES BY MEANS OF INTEGRATED LOGISTICS SUPPORT
}

\author{
K.R. Lambert ${ }^{1 *}$
}

\section{ARTICLE INFO}

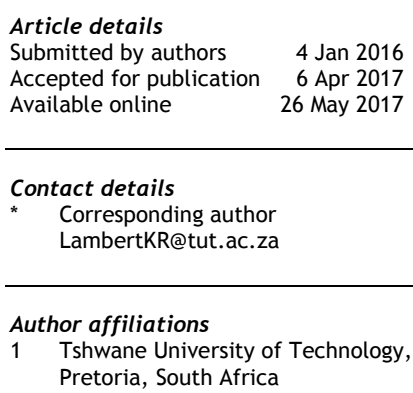

DOI

http://dx.doi.org/10.7166/28-1-1455
ABSTRACT

The business environment is constantly changing. For organisations to gain competitive advantage, they require innovative methods to achieve future business goals. The capital assets of an organisation, such as its high-technology, complex systems, typically have long life-cycles, and are susceptible to obsolescence, requiring multifaceted support. Implementing integrated logistic support principles in supporting such systems improves the organisation's bottom line and reduces the total ownership and life-cycle costs. The research consists of a literature review, a case study analysis, and a questionnaire.

\section{OPSOMMING}

Die sake-omgewing verander voortdurend. Om 'n kompeterende voordeel te verkry benodig organisasies innoverende metodes om toekomstige besigheidsdoelwitte te behaal. Die kapitaalbates van 'n organisasie, soos hoë-vlak tegnologie en komplekse stelsels het tipies lang leefsiklusse en is geneig om te verouder, wat veelsydige ondersteuning vereis. Die implementering van logistiese ondersteuningsbeginsels in sulke stelsels verbeter die organisasie se winsgrens en verminder die totale eienaarskap- en leefsikluskostes. Hierdie navorsing bestaan uit 'n literatuurstudie, 'n gevallestudie analise en 'n meningsopname vraelys.

\section{INTRODUCTION}

The business environment is in constant flux. For organisations to gain competitive advantage, different methods are required to achieve future business goals. The capital assets of an organisation, such as its high-technology, complex systems, typically have long life-cycles, and are susceptible to obsolescence. These systems require complex support - in particular, those that have long or extended life-cycles. Jane's [1] mentions that the life-cycle of components from defence contractors is between seven and 15 years, whereas government life-cycles typically last from 25 to 40 years. In order for such complex systems to meet operational objectives, an integrated logistics support system (ILSS) is needed.

High-technology, complex systems encompass numerous distinctive and intricate assemblies and sub-systems that need to be supported and maintained if the entire system is to function as designed. These systems sometimes consist of fleets, which in itself makes their support a challenge. The systems are often ones whose failure could have dire consequences, requiring maintenance and support during their intended operational life, and sometimes during their extended life. They typically suffer from component obsolescence because suppliers no longer support the product; and they are subsequently upgraded to improve their designed performance. Component obsolescence may be viewed in terms of diminishing manufacturing sources and material shortages (DMSMS). Sufficient planning for cannibalisation, disposal, modifications, mothballing, phase-out, refurbishment, upgrades, and waste could minimise the risks associated with integrated logistics support (ILS).

Given the above, this article's main aim is to determine whether various ILS aspects (viz., the determinants of obsolescence, economic decisions about supply support, the possible causes of 
errors by maintenance personnel, and types of failures/defects) differ between job orientation on the one hand, and knowledge and experience on the other.

ILS was developed in the military, and is currently being used in a number of industrial applications such as navigational aids, rail, petrochemical plants, nuclear power plants, satellite earth stations, and radar. ILS combines all of the logistics elements to support a system or business. Combining these involves understanding how the elements are linked and how each one affects the others [2]. ILS, as mentioned by Jones [3], is an "internationally accepted analysis methodology and management process". The policy of the UK Ministry of Defence (MoD) [4] dictates that "...ILS shall be applied to all product procurement", but uses the word 'acquisition' instead of 'procurement' [5]. ILS comprises various sub-elements. These are listed in Table 1 below.

Table 1: Integrated logistics support elements

\begin{tabular}{|l|l|l|}
\hline Maintenance support & Computer resources & Support and test equipment \\
\hline Obsolescence & Manpower and personnel & Configuration management \\
\hline Supply support & Training and training devices & Technical data and documentation \\
\hline Disposal & Facilities & System operational requirements \\
\hline Packaging, handling, storage and transportation & Reliability, availability and maintainability \\
\hline \multicolumn{2}{|l|}{ The traditional ILS elements are expanded by the US Defense Acquisition University (DAU) (2011) to include } \\
\hline
\end{tabular}

Sources: [6], [7], [8], [3], [4], [9], [10] and *[11].

Defence logistics research was already being published in peer-reviewed journals during the 1950s [12]. In their research, Yoho, Rietjens and Tatham searched for the terms "defence logistics", "military logistics" and "defense logistics" in key words, titles, abstracts and texts, and found 276 peer-reviewed journal articles between 1952 and 2010. Most of these were in specialised military journals. The Air Force Journal of Logistics contained 23.6 per cent of those articles.

\section{ILS IN PRACTICE}

According to the UK MoD [5], the cost of support over a system's life-cycle is greater than the acquisition cost. Equipment maintenance makes up a substantial proportion of the operating cost [13]. Thompson [14] argues that the complex technology found in military systems requires specialised support, frequently provided solely by the original equipment manufacturer (OEM). On the other hand, military system logistics support is provided by industry contractors [15], who must have the necessary resources and skills to support a system - without which the lives of many service personnel are in danger.

In military and industrial procurement programmes, ILS is a stipulated contract item. It is also used in the operational phase of military and industrial systems in South Africa. These include military radar ([16-18]), satellite earth stations, the design of modular nuclear reactors, and industrial and military instrument landing systems [16].

Elsewhere in the world, ILS is used by the European Aeronautics Defence and Space Company [19]; the T-129 attack helicopter [20]; the F-35 joint strike fighter program [21]; the Australian Defence Force [22]; and it enabled cost savings on the H-1 Bell helicopter [23]. It allowed Boeing's life-cycle support system to be shared with other users [24], while life-cycle support services are provided by Patria [25]. For a system to be maintained and supported during the operational phase of its lifecycle, its design is influenced by ILS. While a system's life-cycle is often extended beyond its initial designed life (Blanchard and Trovato in [3]), obsolescence is a major issue, since suppliers no longer keep an inventory of components. Lack of training (or obsolescence) and the inadequate training of personnel can thus cause major problems.

\section{RESEARCH APPROACH}

This study involved empirical research, where primary data was collected by means of case studies and a survey questionnaire. The research had three phases. The literature was analysed in phase 
one; six case studies were Investigated in phase two; and quantitative research was undertaken in the third and final phase.

\subsection{Phase 1: Literature analysis}

Here the maintenance and obsolescence aspects of ILS are explained. Maintenance is a task performed to restore a failed item to a specific operational condition. Coetzee [42] mentions that a "properly managed maintenance function creates and maintains high levels of availability, reliability and operability" at an acceptable cost. A maintenance philosophy sets out a company's position in respect of the maintenance it should perform and where it will be done. This could entail deciding whether to discard or repair a failed item, and determining whether corrective or preventive maintenance should be performed.

The maintenance concept emanates from the maintenance philosophy, but it also provides inputs to the maintenance plan. Such inputs include logistics support analysis (LSA), maintenance planning, and the maintenance concept. According to Blanchard and Fabrycky [26], "a detailed plan for maintenance is developed from the maintenance concept, the ongoing maintenance planning effort accomplished throughout system design, and the results from the logistics support analysis". Included in the concept are tasks that need to be performed at different levels of maintenance, scheduling such tasks, maintenance level policy, support elements, organisational responsibilities, effectiveness requirements, the support and maintenance environment, and the availability of resources ([27-30]). The maintenance concept requires a comprehensive analysis of the system [8]. Inputs for maintenance plan purposes originate from this concept, including support for a specific item of equipment or a system. Maintenance planning includes defining the requirements and creating maintenance support concepts ([27], [30-32], [10]).

Maintenance actions are predictive (monitoring a condition), corrective (unscheduled or unplanned maintenance), or preventative (scheduled inspection or servicing - i.e. daily, weekly, monthly, six monthly, yearly). Blanchard [41] discusses corrective and preventive maintenance, and includes "all software maintenance that is not initially planned, such as adaptive maintenance and perfective maintenance" in corrective maintenance. All likely failures (or failure modes), their effects and criticality, are determined by an analysis of these issues (FMECA) ([6], [27], [33]). Maintenance tasks (e.g., install, calibrate, lubricate) are derived from the FMECA ([27], [34]). The support elements that are necessary to perform such tasks are derived from a maintenance task analysis. For specific tasks, it is necessary to determine who is responsible for them, what actually needs to be done, and with what resources/equipment. A maintenance task analysis will identify resources required (including, but not limited to, facilities, manpower, spare parts, test equipment, tools, and training). Maintenance tasks are allocated numerous sub-tasks; resources are identified to conduct these ([6], [3]).

As indicated, many systems that have long life-cycles are affected by obsolescence. Although the discussion has focused largely on the defence industry, many other industries - e.g., medical, nuclear, petrochemical, power, railways, and telecommunications - are also affected [31]. As noted, obsolescence can be described as diminishing manufacturing sources and material shortages (DMSMS), which concerns "the loss or impending loss of manufacturers or suppliers of critical items and raw materials due to discontinuance of production" [35]. Contemporary and legacy hightechnology systems are suffering from the effects of obsolescence [2]. In his research, Meyer [43] argues that the factors that contribute to component obsolescence include rapid technology advancement, political and legislation impacts, market forces, and a lack of understanding of component obsolescence problems by designers, logisticians, and management. Risk management strategies have been implemented in legacy programmes to reduce the consequences of obsolescence [2]. If a component is obsolete, so too will be the next application of a higher assembly [36]. Meyer [43] states that, at the onset of a project, an obsolescence management plan must be produced and implemented.

Obsolescence can cause a system to become non-operational through the lack of components; so the system might need to be redesigned (part redesign or modification), ensuring that a new component functions within the system. Different product lines supersede old components due to the advancement of technology. In high-technology complex systems, DMSMS is the stage in a system's life-cycle when spare and repair parts are no longer supplied or are in short supply. Obsolescence also affects support and test equipment, the knowledge and skills of staff, and 
organisational processes and procedures. The total cost of ownership, and life-cycle costs, can increase due to system upgrades that result from the use of components with a short life-cycle.

\subsection{Phase 2: Case study deconstruction}

In phase 2, multiple case studies were investigated. The ILS systems/aspects of six high-technology systems were analysed. Failures of these systems have severe consequences, not least because they have a long life-cycle (typically 40 years or more). Of the case studies researched, one system was in the design phase before being shelved, while the other five systems are in the operational phase of their life-cycle. Three have been in operation for less than 10 years, while two others are older than 30 years and have been upgraded. Yin [37] mentions that there are different types of case study design, ranging from a "single case design" and a "single unit of analysis" to "multiple case designs" and "multiple units of analysis". A multiple case and single unit of analysis, which is at system level, was used for this study. The reliability and validity of the study is justified by using multiple case studies, as doing so makes the evidence more credible (Herriott and Firestone in [37]).

All the equivalent systems have a maintenance concept or logistics support concept in place that details the different maintenance level responsibilities. The systems exhibit varying levels of maintenance. One system has four maintenance lines, and three have three maintenance levels (operational, intermediate, and depot). One system has two maintenance levels (operational and depot) while another uses three levels of maintenance split into five tiers: Tier one is equivalent to depot level, while the second tier is equivalent to both depot and intermediate levels; tiers three, four and five are equivalent to the operational level. Although the systems stipulate different levels of maintenance, the management is detailed, and all involved are aware of their responsibilities for maintenance. All of the systems in operation have an implemented maintenance plan. Support contracts are in place between the contractor and the end-user organisation. The latter typically performs O-level (operational level) maintenance - i.e., black box exchange - whereas the former performs D-level (depot level) maintenance - i.e., component replacement.

Obsolescence issues differ between the systems. The two systems that have been in operation for more than 30 years encounter component obsolescence issues. They have been upgraded with new technology in order to improve/enhance the system performance. Some assemblies and subassemblies have been modified to match new components. Some suppliers simply do not manufacture old product lines. The users of these two systems are effectively managing obsolescence. Besides component obsolescence, skills are limited, as personnel have either left the organisation or retired, and their knowledge might not have been transferred to junior personnel; so the loss of critical skills negatively affects the support of the system.

\subsection{Phase 3: Quantitative research}

Key areas were established from the case study analysis and literature review that needed more specific research. A questionnaire, targeted at three job levels in the organisations - management, engineering, and maintenance - was developed. A pilot study was conducted on a sample of individuals who would also complete the final questionnaire. The final questionnaire was distributed to 566 respondents at companies involved in ILS. They included engineering and maintenance/support contractors, and the end-user support/maintenance organisation. Two questionnaires were used during the final data collection stage. The first was paper-based and was distributed to the military, whereas the second was web-based; the link was distributed to companies in the industry. The difference between the two was that the questionnaire for the military organisation required security clearance, as it was deemed that some questions required sensitive information to be given in the answers. The questionnaire despatched to the industry organisations was similar to that for the military, but contained some additional questions. Overall, the response rate for the questionnaires was 33 per cent. A higher response rate was obtained from the military than from the industry companies.

Section $\mathrm{A}$ of the questionnaire asked one question about demographic/general information, and specifically about job orientation. In Section B there were five questions. Question 2 asked about the respondent's experience and knowledge. Question 3 asked about the determining of obsolescence. Question 4 was about economic decisions about supply support. Question 5 asked the respondents to indicate possible causes of maintenance personnel error. In the final question, Question 6, respondents were asked to rate different types of failures/defects. 
The responses from the questionnaires were analysed by means of a contingency table. This compares two or more populations, and is often termed a 'cross-classification' table or a 'crosstabulation' table. It is used to list the "frequency of each combination of the values of the two variables" [38]. A contingency table further allows the researcher to assess one variable's dependence upon other variables [39]. A test statistic, the Chi-square test, was also used for the contingency table. "The chi-squared test of a contingency table is used to determine whether there is enough evidence to infer that two nominal variables are related and to infer that differences exist among two or more populations of nominal variables" [38]. A five per cent significance level was used to test the Chi-square statistic. If the $P$ value probability was below five per cent, then the null hypothesis was rejected, and the dependence of the two variables was established. Cramer's V is "a statistic measuring the strength of association or dependency between two (nominal) categorical variables in a contingency table" [40]. This was used to assess the dependence of the two variables. Table 2 below provides the results of the analysis of the questionnaire data.

Table 2: Results of areas of concern vs knowledge and experience, and job orientation

\begin{tabular}{||l|l|l|l|l||}
\hline \multirow{2}{*}{ ASPECT } & \multicolumn{2}{|l|}{ KNOWLEDGE AND EXPERIENCE } & \multicolumn{2}{l||}{ JOB ORIENTATION } \\
\cline { 2 - 5 } & CHI-SQUARE & CRAMER'S V & CHI-SQUARE & CRAMER'S V \\
\hline \hline Cost to repair & 0.0401 & 0.1641 & 0.5021 & 0.0958 \\
\hline Cost to support & 0.7087 & 0.0766 & 0.0123 & 0.1891 \\
\hline Failure probability & 0.0308 & 0.1696 & 0.4227 & 0.1035 \\
\hline Lead-time to repair & 0.0487 & 0.1607 & 0.0091 & 0.1931 \\
\hline Maintenance-induced failures & 0.8874 & 0.0938 & 0.0298 & 0.2874 \\
\hline Operator-induced failures & 0.5126 & 0.1588 & 0.0330 & 0.2840 \\
\hline Poor supervision & $\mathbf{0 . 0 2 0 9}$ & 0.2983 & 0.6560 & 0.1369 \\
\hline Reliability of repaired system & $\mathbf{0 . 0 0 4 9}$ & 0.2003 & 0.2224 & 0.1252 \\
\hline
\end{tabular}

A discussion of Table 2 follows. Errors committed by maintenance personnel could be attributed to poor procedures and training due to inadequately-defined maintenance concepts. The most important factor causing maintenance problems was maintenance work errors. In addition, the main cause of defects and failures in a system can be attributed to operator-induced errors. The respondents believed that a considerable proportion of a high-technology system's downtime results from operator errors and maintenance-induced errors. The respondents did not regard poor supervision as a key factor contributing to errors made by maintenance personnel. However, they did regard maintenance personnel errors to be a result of poor training and procedures.

The lead-time to repair high-technology systems is critical. For the purpose of maintenance planning, it is important that failure rates are known, ensuring that the necessary resources are available. Having resources and inventory on hand is one way to reduce downtime. The support and reliability of a system is affected by the high failure rate of components. Irrespective of their knowledge base and experience, the respondents viewed 'probability of failure', 'reliability of repaired system', and 'cost to repair' as critical economic decisions about supply support. The respondents also view analysis in the form of FMECA-RCM (failure modes and criticality analysis reliability centred maintenance), level of repair, and logistics support analysis as important factors in drawing up the maintenance plan, concept, and philosophy. In determining a system's life-cycle cost and total cost of ownership, the cost of support is an important factor in obsolescence. Maintenance work is adversely affected by inadequate strategic maintenance objectives, philosophy, and guidelines. If procedures, processes, and actions are unclear, this can result in maintenance staff changing line replaceable units (LRUs) until the fault has disappeared, instead of following diagnostic guidelines.

For maintenance to be efficiently and effectively accomplished, the following grounded technological rules are proposed:

1) Ascertain the risks associated with the maintenance of the system, and manage these risks

2) Conduct specific analysis of the system

3) Delineate the maintenance concept of the specific system and its linkage to other systems

4) Develop maintenance planning, including analysis

5) Document a maintenance plan for the specific system

6) Establish the organisation's maintenance philosophy

7) Implement the maintenance plan across all maintenance levels

8) Use the defined business strategy (Lambert, 2008). 
Insights from this study include: continuously train (retrain) maintenance personnel to reduce maintenance work errors; improve procedures; and retrain operators who use the system, in order to reduce operator error. This will assist in reducing the downtime of the system. Also, ensure sufficient inventory is on hand to reduce downtime; conduct FMECA-RCM and logistics support analysis; and implement an obsolescence plan.

This article's main aim was to determine whether various ILS aspects - determinants of obsolescence, economic decisions about supply support, possible causes of maintenance personnel error, and types of failures/defects - differ between job orientation, and knowledge and experience. These objectives were achieved in this study.

\section{CONCLUSION}

In conclusion, by implementing an ILS system (ILSS), a company can gain competitive advantage and future business opportunities in the market place through managing obsolescence, the DMSMS constraints, and a skills shortage, thus reducing the risks associated with an inadequatelyimplemented ILSS. This risk reduction could ensure that the intended lifespan of a system is reached, and might extend its lifespan. The shortage of skilled personnel is another serious challenge, as it can cause maintenance- and operationally-induced errors that negatively affect the support of a system. An obsolescence management action list must be developed and reviewed on a regular basis to reduce the risks associated with obsolescence and to improve system performance.

Implementing an ILSS offers numerous advantages, including reducing the total cost of ownership and life-cycle costs, and improving the company's bottom line. The firm's market share could increase as customers and suppliers appreciate the value added by the service. Long lead-time effects and the risk of obsolescence are likely to be reduced by the efficient and effective management of inventory. Staff with relevant and appropriate skills sets will, in all probability, be attracted to and retained by the company. Cannibalisation, modification, mothballing, refurbishment, and upgrades will probably be managed successfully. In short, the system's reliability and availability should be significantly improved.

\section{REFERENCES}

[1] Jane's. 2000. The evolution of COTS in the defence industry, Jane's Defence Business News. 09 October 2000. [Online] Available from http://www.janes.com. Accessed: 20 September 2007.

[2] United States Defense Microelectronics Activity. 2001. Government/Industry Microelectronics DMSMS Workshop 2001 Minutes. Folsom, California.

[3] Jones, J.V. 2006. Integrated logistics support handbook, $3^{\text {rd }}$ ed. New York: SOLE Logistics Press, McGrawHill.

[4] United Kingdom Ministry of Defence (MoD). 2010. Ministry of Defence, Defence Standard 00-600. Integrated logistic support. Requirements for MOD Projects Issue 1. [Online] Available from http://www.dstan.mod.uk/standards/defstans/ 00/600/00000100.pdf. Accessed: 07 May 2011.

[5] United Kingdom Ministry of Defence (MoD). 2012. The defence logistic support chain manual, Volume 7 , Integrated Logistic Support; Part 1, Integrated Logistic Support Policy, Version 2.4. JSP 886. [Online] Available from https://www.gov.uk/. Accessed: 13 March 2013.

[6] Blanchard. B.S. 2004. Logistics engineering and management, $6^{\text {th }}$ ed. New Jersey: Pearson Prentice Hall.

[7] Carpenter, J.L. 1967. Integrated logistics support. Hanover, MD: NASA Center for Aerospace Information.

[8] Finkelstein, W. and Guertin, J.A.R. 1988. Integrated logistics support: The design engineering link, $1^{\text {st }}$ ed. London: IFS Publications, UK and Springer-Verlag.

[9] United States Department of the Army. 1999. Integrated logistic support (ILS) manager's guide. Pamphlet 700-127. Washington, DC: Department of Defense.

[10] United States Department of Defense (DoD). 1988. Integrated logistic support program requirements. MIL-STD-1369-A. Washington, DC: Department of Defense.

[11] United States Defense Acquisition University. 2011. Integrated product support element guidebook. [Online] Available from https://acc.dau.mil/. Accessed: 03 April 2013.

[12] Yoho, K.D., Rietjens, S. and Tatham, P. 2013. Defence logistics: An important research field in need of researchers, International Journal of Physical Distribution \& Logistics Management, 43(2), pp. 80-96. [Online] Available from www.emeraldinsight.com. Accessed: 29 May 2015.

[13] Murthy, D.N.P, Atrens, A. and Eccleston, J.A. 2002. Strategic maintenance management, Journal of Quality in Maintenance Engineering, 8(4): 287-305. [Online] Available from www.emeraldinsight.com. Accessed: 04 January 2016.

[14] Knickerbocker, B. 2007. Silent surge in contractor 'armies' a key support for US forces in Iraq and Afghanistan: Civilians have little oversight and, back home, little help, The Christian Science Monitor, 18 July 2007. [Online] Available from http://www.csmonitor.com. Accessed: 04 January 2016. 
[15] MarketResearch.com. 2006. Conference documentation: Contractor logistics support, 06 November 2006. [Online] Available from: http: //www.marketresearch.com. Accessed: 20 September 2007.

[16] Lambert, K.R. 2008. The development of a framework for an integrated logistics support system within a high technology industry in a developing country. Unpublished doctoral thesis. Pretoria: UNISA.

[17] Engelbrecht, L. 2011. Tellumat looking after Umlindi. [Online] Available from http://www.defenceweb.co.za. Accessed: 04 January 2016.

[18] Reutech. 2012. Defence system logistic engineering services, from Reutech. [Online] Available from http: //www.reutechsolutions.com. Accessed: 14 March 2013.

[19] European Defence Agency (EDA). 2007. Annual list of contractors for 2006, 28 March 2007. [Online] Available from http://www.ted.europa.eu. Accessed: 20 September 2007.

[20] Turkish Defence News. 2007. The contract for ATAK program is signed, 17 September 2007. [Online] Available from http://defencetr.blogspot.com. Accessed: 20 September 2007.

[21] Floyd, D. and Reyes, M. 2014. Application of the integrated product support elements, Defense AT\&L, July-August 2014. [Online] Available from: www.dtic.mil/cgi-bin/GetTRDoc?AD=ADA608661. Accessed: 29 May 2015.

[22] Defence Materiel Organisation (DMO). 2007. About DMO. [Online] Available from http://www.defence.gov.au/dmo. Accessed: 05 January 2008. Now called "Capability Acquisition and Sustainment Group"; accessed: 04 January 2016.

[23] Gething, M.J. 2001. Bell rolls out first AH-1Z Super Cobra for USMC, Jane's Naval Forces News, 29 June 2006. [Online] Available from http://www.janes.com. Accessed: 20 September 2007.

[24] Kemp, D. 2006. RAF Chinook support opens international market for Boeing, Jane's Air Forces News, 29 June 2006. [Online] Available from http://www.janes.com. Accessed: 20 September 2007.

[25] Patria. 2013. Products and services. [Online] Available from http://patria.fi/en/ products-and-services. Accessed: 04 January 2016.

[26] Blanchard, B.S. and Fabrycky, W.J. 1990. Systems engineering and analysis, $2^{\text {nd }}$ ed. New Jersey: PrenticeHall International, Inc.

[27] Jones, J.V. 1995. Integrated logistics support handbook, $2^{\text {nd }}$ ed. New York: McGraw-Hill.

[28] Blanchard. B.S. 1992. Logistics engineering and management, $4^{\text {th }}$ ed. Englewood Cliffs: Prentice-Hall.

[29] Langford, J.W. 1995. Logistics: Principles and applications. New York: McGraw-Hill.

[30] Biedenbender, D., Vryn, F. and Eisaman, J. 1993. The ILS manager's LSA toolkit availability engineering. New York: McGraw-Hill.

[31] United Kingdom Ministry of Defence (MoD) Corporate Technical Services. 2004. Ministry of Defence, Component Obsolescence Resolution Cost Metrics Study Report. QinetiQ and ARINC.

[32] United States Department of the Army. 2005. Integrated logistic support (ILS) manager's guide. Pamphlet 700-127. Washington, DC: Department of Defense.

[33] United States Department of Defense (DoD). 1980. Procedures for performing a failure modes, effects, and criticality analysis. MIL-STD-1629. Washington, DC: Department of Defense.

[34] United States Department of Defense (DoD). 1991. Department of Defense requirements for a logistic support analysis record. MIL-STD-1388-2B. Washington, DC: Department of Defense.

[35] Tomczykowski, W., Fritz, A. and Scalia, R. 2000. Program manager's handbook: Common practices to mitigate the risk of obsolescence. Maryland: Defense Microelectronics Activity (DMEA).

[36] Boyle, J. 2005. A novel approach to obsolescence management, Defense Electronics, October 2005, pp 2025.

[37] Yin, R.K. 2009. Case study research design and methods, $4^{\text {th }}$ ed. California: Sage Publications.

[38] Keller, G. and Warrack, B. 2003. Statistics for management and economics, $6^{\text {th }}$ ed. Pacific Grove, CA: Brooks/Cole-Thomson Learning.

[39] Howell, D.C. 1995. Fundamental statistics for the behavioral sciences, $3^{\text {rd }}$ ed. Belmont, CA: Wadsworth Publishing Company, International Thomson Publishing.

[40] PlanetMath. 2011. Cramer's V. [Online] Available from http://planetmath.org/ cramersv. Accessed: 04 January 2016.

[41] Blanchard, B.S. 2004. Logistics engineering and management, $6^{\text {th }}$ ed. New Jersey: Pearson Prentice Hall.

[42] Coetzee, J.L. 2004. Maintenance. Victoria: Trafford Publishing.

[43] Meyer, A. 2004. A model to manage component obsolescence in the South African context. Unpublished doctoral thesis. Johannesburg: Rand Afrikaans University. [Online] Available from https://ujcontent.uj.ac.za/vital/access/manager/ Repository/uj:3171. Accessed: 17 November 2016. 


\section{APPENDIX A INTEGRATED LOGISTICS SUPPORT (ILS) RESEARCH QUESTIONNAIRE}

Please answer the questions below, either mark them with a cross " $x$ " or a tick " $\checkmark$ ", or circle the appropriate option, or highlight the appropriate option, or write/complete the appropriate answer.

\section{SECTION A: DEMOGRAPHIC/GENERAL INFORMATION - FOR STATISTICAL PURPOSES ONLY}

Although the following question within this section may be personal, please be so kind as to complete the question, the information will be kept strictly confidential. The information will strictly be used for statistical demographic purposes only.

\begin{tabular}{|l|l|l|l|l|}
\hline 1) & Job orientation? & Engineering & Maintenance & Management \\
\hline
\end{tabular}

\section{SECTION B: INTEGRATED LOGISTICS SUPPORT - HIGH TECHNOLOGY SYSTEM RELATED}

In order to understand the context with which you are answering the remainder of the questionnaire, please indicate your experience \& knowledge base below in question 2:

\begin{tabular}{|l|l|l|l|l|l||}
\hline \hline 2$)$ & $\begin{array}{l}\text { Design of } \\
\text { new system }\end{array}$ & $\begin{array}{l}\text { Maintenance (relatively } \\
\text { new system, less than } \\
\text { five years old) }\end{array}$ & $\begin{array}{l}\text { Maintenance (system } \\
\text { older than five years) }\end{array}$ & $\mid$ \\
\hline
\end{tabular}

Please rate the importance of the following statement with respect to determinants of obsolescence as they relate to your high-technology system on a scale of 1 to 5 , where "1" is most important and " 5 " is least important.

\begin{tabular}{|l|l|l|l|l|l|l|}
\hline 3$)$ & Cost to support & 1 & 2 & 3 & 4 & 5 \\
\hline
\end{tabular}

Please rate the importance of the following statement with respect to economical decisions as they relate to supply support as they relate to your high-technology system on a scale of 1 to 5 , where "1" is most important and " 5 " is least important.

\begin{tabular}{|l|l|l|l|l|l|l|}
\hline 4a) & Cost to repair & 1 & 2 & 3 & 4 & 5 \\
\hline 4b) & Failure probability & 1 & 2 & 3 & 4 & 5 \\
\hline 4c) & Lead-time to repair & 1 & 2 & 3 & 4 & 5 \\
\hline 4d) & Reliability of repaired system & 1 & 2 & 3 & 4 & 5 \\
\hline
\end{tabular}

In your opinion please sort ( 1 to 3 ) the options to the following statements as they relate to your high-technology system, where: Most important $=$ "1", and " 3 " = Least important. An example is given below.

\begin{tabular}{|l|l|l|l|}
\hline 5) & $\begin{array}{l}\text { Possible causes of } \\
\text { maintenance personnel error }\end{array}$ & Inadequate work space or work layout & \\
\cline { 3 - 4 } & & Poor supervision & \\
\cline { 3 - 4 } & & Poor training \& procedures & \\
\hline
\end{tabular}

\begin{tabular}{|l|l|l|l||}
\hline 6$)$ & Types of failures/ defects & Maintenance induced failures & \\
\cline { 3 - 4 } & & Operator-induced failures & \\
\cline { 3 - 4 } & & Wear-out (predictable) failures & \\
\hline
\end{tabular}

